\title{
anemon
}

Muş Alparslan Üniversitesi Sosyal Bilimler Dergisi

Journal of Social Sciences of Muş Alparslan University

Yı//Year: 2016 • Cilt/Volume: 4 • Sayı/Number: 2

ISSN: 2147-7655 • e-ISSN: 2149-4622

ÖZGÜN ARAŞTIRMA • ORIGINAL ARTICLE

\section{Kamu Yönetiminde Tek Tipçi Kurumsal Yapılanma Sorununa Kalkınma Ajansları Üzerinden Hermenütik Kuramla Analiz ve Çözümleme}

\author{
Ahmet EFE ${ }^{1, a}$ \\ ${ }^{1}$ Dr., Ankara Kalkınma Ajansı, İç Denetim Departmanı, Ankara/ Türkiye \\ Başvuru tarihi: 22 Ocak 2016 Düzeltme tarihi: 24 Haziran 2016 Kabul tarihi: 8 Ağustos 2016
}

Öz

Türkiye'de 2006 yılından itibaren kurulmaya başlayan kalkınma ajansları (KA) 2010 yılı sonu itibariyle sayıları 26 olarak AB Düzey-2 bölgelendirme sistematiğine göre kuruluşlarını tamamlamışlardır. Ancak aradan geçen birkaç yıllık süreçte bunların kuruluş felsefesinden uzaklaştıkları ve etkin işletilemedikleri gibi eleştirilerle karşılaşmışlardır. Devlet Denetleme Kurulu (DDK) tarafından 2014 yılında yapılan bir incelemede 43 adet sorun alanları belirlenmiştir. Bu çalışmada tek tipikliğe çoklu disipliner ve kuramsal bir bakış açısıyla inceleme yapılabileceği ve görelilik ve görelilik teorisi çerçevesinde çözümleme yapılabileceği analizlerle gösterilmiştir. Araştırmamızda, teknik ve yönetim süreçleriyle ilgili çerçeve ve yöntemlerin görelilik teorisinden etkilendiği iddiasıyla DDK tarafından belirlenmiş sorunlardan birisi olan tek tipçi yapılanmanın COBIT-5 paydaş ihtiyaçları çerçevesinde yapılanma gerekliliğine dair hedef basamakları modelinin uygulanabilirliğinin tartışması yapılmaktadır.

\section{Anahtar Kelimeler}

Tek Tipçilik, Bölgesel Kalkınma Ajansı, Yorumsalcılık, Görelilik

\footnotetext{
a Sorumlu Yazar/Correspoding Author: Ankara Kalkınma Ajansı, Aşağı Öveçler Mah., 1322. Cad., No: 11, 06460, Çankaya / Ankara / Türkiye.

e-posta: aefe@ankaraka.org.tr

doi : $10.18506 /$ anemon. 258534

URL: http://dergipark.gov.tr/anemon

Copyright @ 2013-2016 Muş Alparslan Üniversitesi
} 


\title{
A Theoretical and Conceptual Analysis with Hermeneutics Theory over Solution Finding Based on COBIT Approach for the Regional Development Agencies' Monolithic Structure
}

\begin{abstract}
The development agencies which have been founded in Turkey since 2006 according to NUTS-II the EU regional classification system have reached to a number of 26 at the end of 2010 . However, after a few years of operations, the agencies have faced some criticisms such as being diverted from the way they had been headed at the beginning and not being as effective as they should be in their operations. According to a study issued by State Auditing Board (DDK), 43 different structural problematic areas have been detected. In this study, with different concepts and paradigms such as digital hermeneutics and relativity, a theoretical and conceptual relational analysis is being done in order to find a solution to one of the problems defined by DDK which is the stereotyped structure of development agencies. With an approach of conceptual and theoretical analysis to the stereotyped structures, it is found that it is possible to find solutions with the model of "meeting stakeholders' needs" a principle of COBIT-5 framework.
\end{abstract}

Keywords

Stereotyped, Regional Development Agency, Hermeneutics, Relativity

\section{GİRIŞ}

Türkiye'de 2006 yılında “yönetişim” paradigması üzerine kurgulanan Kalkınma Ajansları (KA), 5449 sayılı Kuruluş Kanunu ile ortaya çıkmış olmakla birlikte pek çok gelişmiş ülkede yaygın olarak kullanılan bölgesel gelişme ve sosyal-ekonomik dinamiklerin verimli bir şekilde harekete geçirilmesine olanak tanımayı amaç edinen küçük ölçekli kamu kurumlarıdır. Küresel eğilimler 1şı̆̆ında, Türkiye açısından geleneksel plancilıktan vazgeçilerek yerel sivil, özel, akademi ve kamu sektörünün yönetişimine dayanan planlama kültürü KA ile bölgesel kalkınmacılığa yansıtılmaktadır. KA platformları, üniversite, sanayi, STK, yerel yönetimler ile mülki idarelerin ortak yönetimine dayanan karar mekanizmalarına sahiptirler. Ayrıca, bölgesel kalkınma ve KA ile ilgili koordinasyon görevi olan Kalkınma Bakanlığı bünyesinde kalkınma ile ilgili bilgilerin ortak bir havuzda biriktirilerek elektronik imkânlarıyla verimli ve etkin bir şekilde yönetilebilmesi ve izlenerek rapor edilebilmesine olanak sağlayacak Kalkınma Ajansları Yönetim Sistemi (KAYS) adında bir bilişim sistemi kurulmuştur. Bu sistemin 
geliştirilme süreci TUBITAK Yazılım Teknolojileri Enstitüsü (YTE) tarafindan halen devam edilmektedir.

2006 yılından itibaren kurumaya başlanan ve 2010 yılında 26 adet olarak kuruluşlarını tamamlayan ve halen Kalkınma Bakanlığı tarafından çıkarılan mevzuat güncellemeleriyle bölgesel düzeyde kuruluş amaçları doğrultusunda faaliyetlerine devam etmesi beklenen KA zamanla sadece hibe veren kuruluşlar kategorisinde zikredilmeye başlanmışlardır. Bunun yanı sıra KA tarafından verilen projelerinin küçük çapta kapasite artışlarına yol açmakla birlikte haksız rekabete yol açtığı, bölgesel potansiyelleri ortaya çıkarmada başarılı olmadığı, yerel dinamikleri işbirliği ve ortaklık kültürü ile harekete geçirme istidadını yitirdiği, yönetim ve kalkınma kurullarının beklenen işlevselliği ortaya koyamadığı, personelin motivasyonunun düşük olduğu ve giderek daha bürokratik kurumlar hale geldikleri ve İngiltere'de 2012 yılında yaşandığı gibi aslında kapatılmaları gerektiği gibi pek çok olumsuz söylemin de medyada ve bazı yayınlarda gündeme getirildiği bilinmektedir.

KA'nın varlık nedeninin sorgulanması ve KA ile ilgili zayıflıkların ve problemlerin varlığı ile ilgili olarak siyasi, bürokratik, akademik ve iş dünyasından gelen olumsuz değerlendirmelerin artması üzerine Cumhurbaşkanlığı makamınca 2012 yılı sonunda görevlendirilmiş olan Devlet Denetleme Kurulunun (DDK) (Aykın vd., 2014) bir araştırma ve inceleme ihtisas heyeti marifetiyle yaptırdığı kapsamlı çalışmalar, neticesinde 43 maddede tespit edilen temel sorunlara parmak basilarak bunların giderilmesi için bazı önerilerde bulunulmuştur. $\mathrm{Bu}$ sorunların yönetişim yapılandırmasıyla ilişkili olduğu savıyla bir kurumsal bilgi teknolojileri yönetişim standardı olan COBIT-5 çerçevesiyle çözümlemelerin yapılabileceği de doktora düzeyinde araştırmalarla ortaya konulduğu tespit edilmiştir (Efe, 2015).

Bahsi geçen DDK raporundaki sorunlardan birisi olan tek tipçilik sorununun COBIT-5 paydaş ihtiyaçlarının karşılanması modeliyle çözülebileceği önermesinin kavramsal ve kuramsal bir analize tabi tutulması önem arz etmektedir. Bu çalışmamızda COBIT-5 paydaş ihtiyaçları modeline göre yapılacak bir kurumsal değişiklik veya yapılandırma şeklinin kavramsal ve kuramsal boyutlarıyla desteklenebileceğinin test edilmesi gerekliliği üzerinde durulmaktadır. Buna göre COBIT-5 paydaş ihtiyaçları yaklaşımı teknik bir süreç iken bunun teorik olarak görelilik yaklaşımıyla desteklenip desteklenemeyeceği araştırma konusu edilmektedir.

Bir paradigma olarak dikkate alınabilecek olan COBIT, önceleri denetim, kontrol ve daha sonra yönetim çerçevesi iken daha sonraları risk ve katma değer ile ilgili standartları da bünyesine alarak zamanla bir BT yönetişim çerçevesi haline gelmiş̧ir. Her versiyonunda paradigmatik bir kırllımla kendisini yenileyen COBIT-5 versiyonunda, en sonunda sadece BT değil diğer iş süreçlerini de kapsayarak kapsamlı bir model haline gelen bütünlükçü, kapsayıcı ve uyarlayıcı bir çerçeve iddiasındadır. COBIT-5 ile ortaya konulan ilkeler ve gerçekleştiriciler ile BT yönetişiminin iş süreçleri ile birlikte yönetilebilmesine olanak sağlayacak bir yönetişim ve yönetim modellemesi süreçleriyle birlikte ortaya konulmaktadır.

COBIT- 5 çerçeve yaklaşımı 5 temel ilke "principles" getirmektedir. Bu ilkeler çerçevenin esas sütunlarını teşkil etmektedirler. Bu ilkeler üzerinde yapılacak olan yapısal kurgu ve 
süreç uygulamaları da gerçekleştiriciler "enablers" vasıtasıyla temellendirilebileceklerdir.

Şekil 1. COBIT-5 Temel İlkeleri

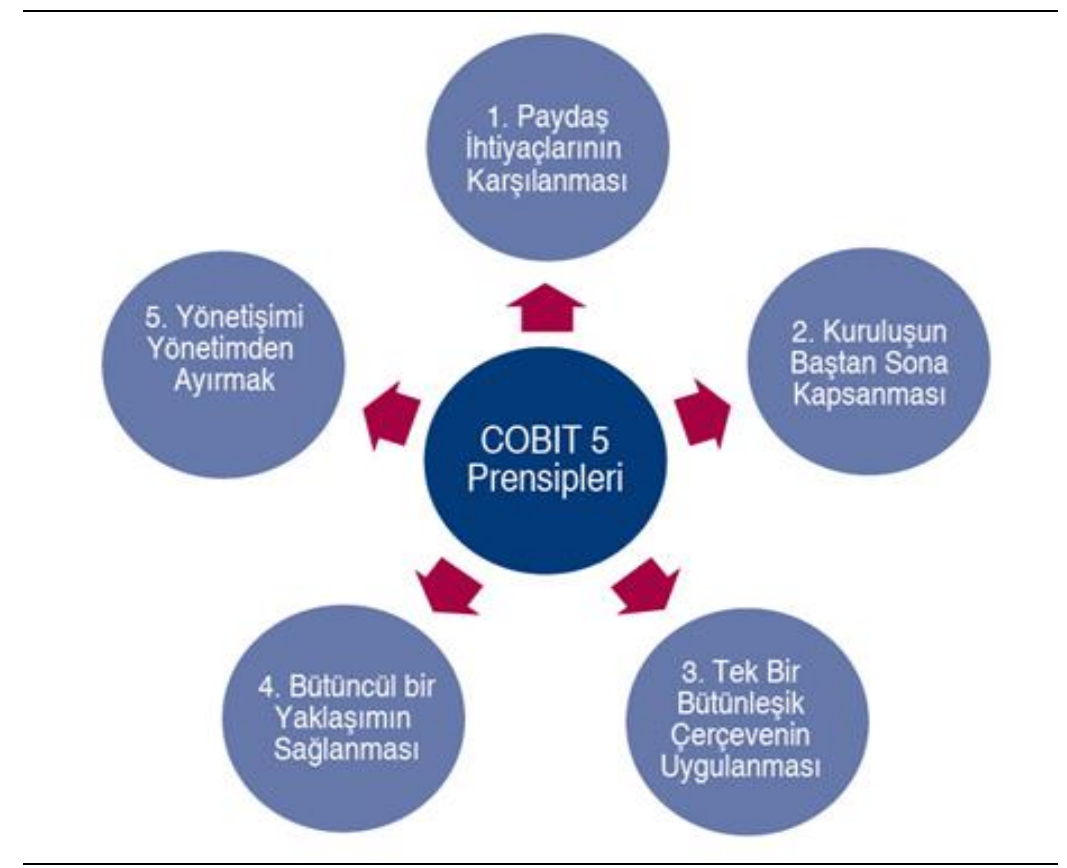

Kaynak: ISACA (2012)

Şekil 1'de görüldüğü gibi COBIT-5 beşinci versiyonunda beş temel ilke üzerinde kurulmuş olup bu çalışmamızda sadece birinci ilke ile ilgili analizler yapılmaktadır. Diğer ilkelerin içerikleri ve KA kapsamında uygulanabilirliği başka çalışmalara konu edilebilir.

COBIT-5 gerçekleştiricileri bütüncül yaklaşımı esas alınarak BT ve iş süreçleri ile birlikte bir kurumsal anlamdaki her şey gerçekleştiriciler kapsamına alınabilmektedir. Gerçekleştiricilerin içerikleri ve yönetişim ve yönetim süreçleri kapsamındaki etkileşimleri bu çalışmaya konu edilmemiştir. 
Şekil 2. COBIT-5 Gerçekleştiricileri

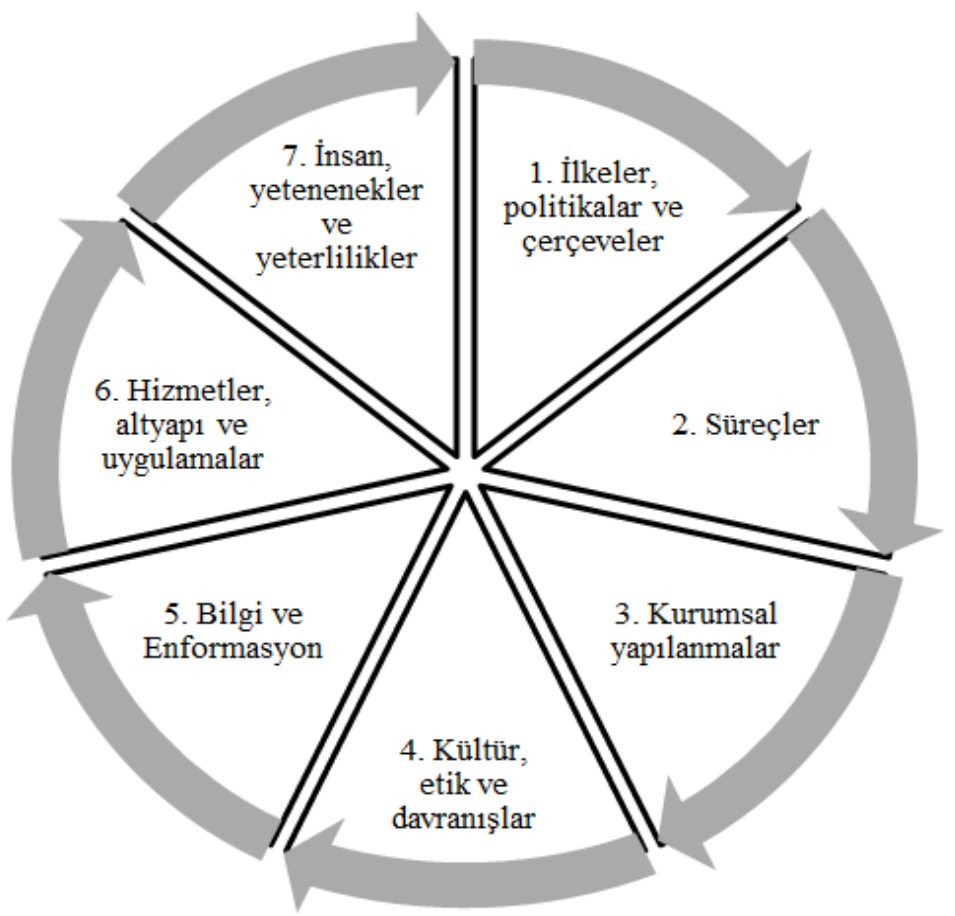

Kaynak: ISACA (2012)

Paradigma olarak ele almaya çalıştığımız COBIT-5, ISACA tarafından geliştirilen bir BT yönetişim çerçevesidir. Şekilden de görüleceği üzere, COBIT, ilk başta finansal ve BT denetim ve kontrol alanlarında ilk önce kendisini göstermişti. İlk baştaki COBIT, "Control Objectives of IT" olarak bilinmekteydi. Daha sonra COBIT, göstergeler, süreç araçları, kritik başarı faktörleri, olgunluk modelleri ve BT yönetimi ile ilgili görev ve sorumluluklarının yerine getirilebilmesi için geliştirilen araçlarla birlikte aşamalı bir şekilde toplumsal ve ekonomik koşulların sonucu olarak yeni olarak elde edilen bilgilerle girdiği paradigma gerilimleri sonucunda bir yönetişim ve yönetim çerçevesi haline gelivermiştir. Paradigma gerilimi, diğer standart ve çerçevelerin mevcut teknik ilişkiler ağını, gereklilikleri ve sürdürülebilir stratejik yönetimi acımasız rekabet ortamında açıklayamaması ve çözüm bulamamasından dolayı ortaya çıkmıştır. Çünkü her kurumun paydaşları ve ihtiyaçları farklı olduğundan ve kaynakları ile riskleri de aynı olmadığından kendilerine has uyarlamaların yapılabilmesi aşikâr bir halde belirginleşmiştir. Kendisini çevresel koşullara ve zamanın gereklerine göre sürekli adapte edebilen COBIT bu gerilim içerisinde yeni bir paradigma olarak ortaya çıkarak mevut sorunlara çözüm sunma iddiasındadır. 
Şekil 3. COBIT Alanında Paradigma Gerilimleriyle Yaşanan Kapsam Genişlemesi

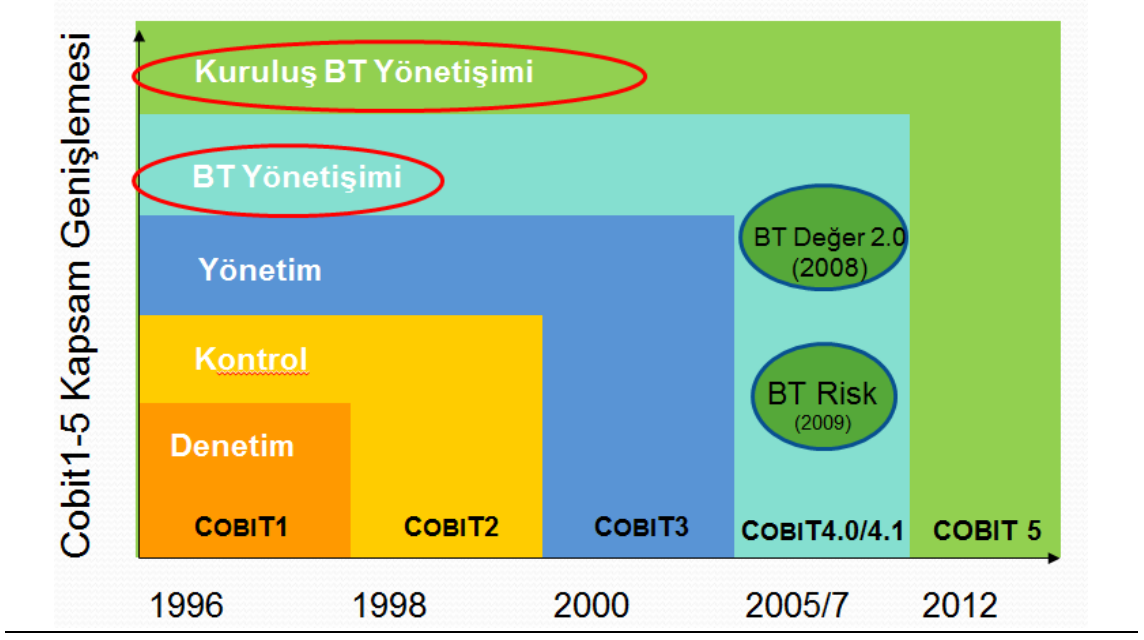

Kaynak: ISACA (2012)

Şekil 3'den de görüleceği üzere, COBIT-4 iş süreçlerini BT süreçleri ile hizalamak için bazı araçların geliştirilmesiyle ortaya çıkmış ve diğer yönetişim çerçeveleri ve BT çerçeve ve standartları ile olan ilişkileri de güçlendirmiştir.

KA uygulama alanıyla ilişkilendirilebilen ve bu alanlara kaynak teşkil edebilen en önemli teorik bağlamlardan olan Görelilik ve dijital görelilik (digital hermeneutics) teorileriyle ilgili olarak bazı değerlendirmelerde bulunulacaktır. Bu değerlendirmelerde ilgili teorilerin derin ve tartışmalı olan ontolojik ve epistemolojik tartışmalarına girilmeden araştırma alanıyla ilişkilendirilebilinen noktalarıyla sınırlı tutulacaktır.

Görelilik ve dijital görelilik buradaki paradigma analizi içerisinde ele alınmasının bir kaç nedeni bulunmaktadir. Bunlar;

- $\quad$ Belirli bir uygulama, süreç veya politikanın her kuruma tek doğru olarak sunulamamas1,

- Her kuruma veya paralel her sürece tek ilaç gibi sunulamaması,

- Kapitalizmin devamlılığına ve sömürü düzeninin güçlenmesine hizmet edebilecek paradigmaların zaman, kurumsal yapılanma, çevresel farklılıklar ve paydaşların ihtiyaçlarına göre dikkate alınarak canlı ve yenilikçi bir sisteme olan ihtiyac1 ortaya koyması

olarak sıralandırılabilir. Dolayısıyla görelilik ve dijital görelilik ile birlikte ortaya çıkan paradigma gerilimi, aslında küreselleşmenin gelişmesi ile birlikte meydana gelen mekân krizi ve ilişkilerin yoğunlaşmasının bilim alanındaki eşzamanlı yansıması olarak değerlendirilebilirler. 


\section{ARAŞTIRMA YÖNTEMI}

Araştırmamızın hipotezi şu şekilde belirlenmiştir: "DDK raporuyla ifade edilen tek tipçi örgütlenme sorunu COBIT hedef basamakları yaklaşımıyla çözümlenebilir ve bu çözümleme görelilik teorisiyle analiz edilebilir".

Araştırmamızda, DDK tarafından KA sorunlarının tespit edildiği ve 43 sorunun rapor edildiği araştırma raporu tespitleri veri alınmıştır. Bu sorun tespitlerinden sadece bir tanesi üzerinde kuramsal analiz yapılarak çözümlenmesine katkıda bulunulmaya çalışılmaktadır. Bu çalışmada kalkınma ajanslarının hedef basamaklarının kullanımıyla ilişkili olabilen sorunları analiz edilmektedir bu amaçla da DDK raporu incelenmiş ve süreç olgunluğu ile ilgili dört adet probleme dair çekirdek neden analizleri yapılmaktadır. Hizmete özel olan DDK raporu üzerinde akademik araştırma yapılarak bu alandaki idari bilgi literatüre kazandırılmaktadır.

Yukarıda problem tespiti kısmında bir iç kontrol standardı olan COSO ve bir bilişim yönetişimi standardı olan COBIT standartları çerçevesinde kök neden analizi de yapılmıştır. $\mathrm{Bu}$ analizler yeterli görülmediğinden dolayı bu standartları etkileyen kuramların ele alınarak tek tipçilik probleminin arka planı analiz edilmektedir. KA tek tipçiliğine karşı COBIT-5 paydaş ihtiyaçlarına göre yapılanma yaklaşımının çözüm önerisi olarak uygulanabilirliği üzerine kuramsal ve kavramsal bir analize ihtiyaç duyulmuştur.

Buna göre COBIT-5 çerçevesi kısaca betimlenmektedir. Görelilik ve dijital görelilik üzerinde kavramsal ve kuramsal ilişkilendirme yapılmaktadır. İşletmecilik, kamu yönetimi, YBS, fizik ve felsefe alanlarına giren bu kavramlar üzerinde yapılan analizler çoklu disipliner analiz kapsamında değerlendirilmektedir.

Araştırma konusuyla ilgili literatür taraması yapılmış̧ır. EBSCO veri tabanında, "COBIT" olarak yapılan taramada 393 adet yayın tespit edilmiştir. Türkçe literatürdeki yayınların bunlar içerisinde sadece 4 yayınla sınırlı olduğu tespit edilmiştir. "hermeneutics" olarak yapılan taramada ise 12.592 adet akademik yayın yapılmış olduğu ve bunlar içerisinde sadece 159 tanesinin Türkçe literatürdeki yayınlar olduğu tespit edilmiştir. Gene "development agencies" olarak yapılan taramada ise 3.585 adet yayının mevcut olduğu ve bunlardan sadece 48 adedinin Türkçe literatür içerisinde olduğu tespit edilmiştir. Dolayısıyla araştırma konusunda yabancı literatürün yeterli olduğu ancak buna nazaran Türkçe literatürün kıyaslanamayacak ölçüde yetersiz olduğu söylenebilir. $\mathrm{Bu}$ nedenle bu araştırmamızın Türkçe literatüre katkısı bakımından önem arz ettiği söylenebilir.

Araştırma konusu olarak ele aldığımız tek tipçilik sorununun sadece yasal ve idari bir takım önlemlerle çözümlenmeye çalışılması bir tarafa, konunun kavramsal ve kuramsal çerçevede analizinin yapılmadığı ve her hangi bir standarda göre değerlendirme yapılmadığı tespit edilmiş̧ir. Buna göre araştırma problemi belirlenmiş ve aşağıdaki sorulara cevap aranmıştır:

(i) KA tek tipçiliği ile ilgili sorun görelilik ve dijital görelilik değerlendirilebilir mi?

(ii) COBIT-5 çerçevesi tek tipçilik sorununa nasıl bir çözümleme getirmektedir ve bu olanaklı midir? 
(iii) COBIT-5 ile getirilebilecek olan çözümleme görelilik ve dijital görelilik çerçevesinde teorik ve kavramsal olarak nasıl konumlandırılabilir?

Yukarıdaki araştırma sorularına cevap bulunması için metodolojik olarak öncelikle konu ile ilgili araştırma problemi yapılandırılmakta, kök neden analizleriyle mevcut sorunların asıl nedenleri araştırılmakta; paydaş ihtiyaçlarını karşılama yaklaşımı betimleyici bir şekilde tanıtılmakta; hedef basamakları uygulama modelinin paydaş ihtiyaçları ve kurumsal yapılandırma ve hedeflerin belirlenmesi kapsamındaki konumlandırılışı çerçevesinde KA dinamiklerine uyarlanması yapılmakta ve en son görelilik kuramının araştırma problemi ve paydaş yaklaşımı ile hedef basamakları yaklaşımıyla olan ilişkisi analiz edilmektedir.

\section{ARAŞTIRMA PROBLEMI}

KA sorunlarının tespit edildiği DDK raporunda yapılan analizde her hangi bir referans model kıstas olarak alınmadığı gibi önerilerde de her hangi bir modele referans verilmemiş olmasından dolayı yapılan araştırmadaki problemlerde eksik kalan analizlerin yapılması da tezin amaçları kapsamına alınmıştır. DDK raporuna cevaben Kalkınma Bakanlığı tarafından $26 \mathrm{KA}$ ile istişare halinde eylem planı hazırlanmıştır. Bu 2014 Eylül ayında hazırlanmış olan hizmete özel taslak eylem planında, Kalkınma Bakanlığı ve KA için ayrı eylemler öngörülmüştür. Aşağıdaki analizlerde bunlar ayrıca dikkate alınmaktadır (KB-BGYUGM, 2014).

DDK tarafindan tespit edilen sorunların ana nedenlerinin tespiti için iç kontrol açısından ve $\mathrm{COSO}$ ve yönetişim açısından COBIT-5 çerçevelerine göre karşılaştırma yapmaya olanak verecek şekilde bir şekilde değerlendirme yapılması ana sorunsalın tespiti açısından önem arz etmektedir. Çünkü ortak sorun bölgesel gelişme yönetişim yapısının sağlıklı olmamasından ve süreçlerinin uygun bir çerçevede belirlenmemiş olmasından kaynaklanmaktadır. Bu nedenle en azından bir sorun üzerinde bilimsel yöntemlerle kuramsal analiz yapılması önem arz etmektedir. Bu amaçla DDK tarafından tespit edilen sorunlardan ilki olan tek tipçilik sorunu araştırma problemi olarak kabul edilmiştir.

Türkiye'de bölgeler arasında coğrafi yapı, ekonomik ve sosyal gelişmişlik, sahip olunan kaynaklar, ulaşım imkânları, beşeri sermaye yapısı, rekabetçilik düzeyi ve yatırım ortamının niteliği gibi pek çok alanda önemli derecede farklılıklar bulunmasına ve 5449 sayılı Kanun'un genel gerekçesinde (TBMM, 2006), KA’nın bölgelerin özgün şartları ve yapılarına göre teşkilat yapılarının, birimlerinin, büyüklüklerinin ve diğer yapısal özelliklerinin özel hale getirilmesi gerektiği vurgulanarak, buna ilişkin özel hukuk alanında gerekli hukuki altyapı hazırlanmıştır. Buna rağmen KA, 26 Düzey 2 bölgesinin tamamında organları, fonksiyonları, bölgesel kalkınmada kullanacağı araçları, personel yapısı, süreçleri, kuralları, işleyiş şekli ve birimlerin görev tanımları gibi tüm unsurları ile tek tip olarak örgütlenmiştir. Bu durum, her bölgenin kendi karakteristik özelliklerine, kaynaklarına ve önceliklerine uygun bir bölgesel gelişme teori ve politikası, uygulamaları ve 5449 sayılı Kanun'un temel amaç ve felsefesi ile uyumlu değildir (Aykın vd., 2014). $\mathrm{Bu}$ nedenle de araştırmamızın temel sorunsalı KA tek tipçi yapılanması olarak belirlenmiştir. 
Tablo 1. DDK tarafından tespit edilen tek tip örgüt yapısı sorunu için COSO ve COBİT-5 değerlendirmesi ve eylem planları

\section{DDK Önerisi}

Bölgelerin rekabet gücü ve gelişmişlik düzeyi ile Ajansların teşkilat yapılarının, büyüklüklerinin, birimlerinin, insan kaynağı profilinin, özlük haklarının, temel fonksiyonlarının, bölgesel gelişmede kullanabileceği araç ve imkânlarına göre yeniden şekillendirilmesi.

\section{COSO değerlendirmesi}

COSO iç kontrol sistemi iç kontrol bileşenlerinden kontrol ortamı alanına girmektedir. Tek tip örgüt yapısı organizasyon yapısı açısından bir iç kontrol zafiyetine yol açmadığı düşünüldüğünden dolayı iç kontrol yaklaşımı açısından sorun değildir.

\section{COBIT-5 değerlendirmesi}

Örgüt yapısının kararlaştırılması yönetişim süreçleriyle ilişkilidir. COBIT-5 birinci ilkesi olan "paydaş ihtiyaçlarının karşılanması" ve üçüncü gerçekleştirici olan "kurumsal yapılanmalar"a uygun olmadığından bir sorundur. Yereldeki ihtiyaçlar ve olanaklar ölçüsünde kurumsal yapılar da değişebilmelidir.

\section{Kalkınma Bakanlığı Eylem Planı}

\section{KA Eylem Planı}

1.1 5449 sayılı Kanun değişikliklerine ilişkin çalışmalarda yönetim kurulunun yapılanması tekrar gözden geçirilecek ve 6360 sayı Kanun sonrası idari teşkilatlanmada gerçekleşen değişiklikler 5449 sayılı Kanuna yansitılacaktır.

1.2 Ajansların ve bölgede yer alan kurum ve kuruluşların kalkınma kurulunda yer alacak üyelere ilişkin talepleri doğrultusunda kalkınma kurullarını düzenleyen yeni bir Bakanlar Kurulu Kararnamesi hazırlanacaktır.

Kaynak: Aykın vd. (2014) ve KB-BGYUGM (2014)

Tablo 1'de tek tipçilik sorununun iki farklı standart kapsamındaki kısaca değerlendirmeleri yer almaktadır. Buna göre tek tipçilik COSO kontrol amaçları ve bileşenleri açısından bir sorun olarak dikkate alınmayabilmekteyken COBIT-5 çerçevesine göre bir yönetişim sorunu olarak dikkate çarpmaktadır. $\mathrm{Bu}$ sorunun giderilmesi için Kalkınma Bakanlığı tarafından hazırlanan eylem planlarında hem Kalkınma Bakanlığı ve hem de KA tarafından alınacak önlemler belirtilmiştir. Ancak sadece Yönetim Kurulu (YK) ile Kalkınma Kurulu (KK) ile ilgili değişikliklerle bölgedeki sorumlulukların gözden geçirileceği ifade edilmekte olduğu gibi henüz bu hususlarda yasal bir düzenleme ve idari değişiklikler yapılmamıştır. Hâlbuki bölgesel kaynak ve ihtiyaçlara göre ilgili paydaşların istediği şekilde bir kurumsal yapı ve hedeflerin ortaya konulabilmesine olanak sağlayacak bir teşkilatlanma imkânının sağlanması gerekir. 


\section{PAYDAŞ İHTIYAÇLARINI KARŞILAMA YAKLAŞIMI}

Paydaşların ihtiyaçlarının karşılanması esasen paydaş yaklaşımı teorisinin bir uzantısı şeklinde anlaşılabilmektedir. 1984 yılında basılan Stratejik Yönetim: Paydaş Yaklaşımı "Strategic Management: A Stakeholder Approach" isimli kitaptan sonra binlerce kitap ve akademik araştırma bu alanda yapılmıştır.

Pek çok konu, tema ve zorluklar; bu kapsamda paydaş tespiti, paydaş meşruiyeti ve isteklerinin değerlendirilmesi ile firmanın veya toplumun bu alandaki rolleri ile ilişkilendirilmişlerdir. Her nasılsa bu alandaki pek çok kapsamı araştırmaya rağmen hala geliştirilmekte olan konu değer oluşturma ve ticarileştirilmesidir. Freeman'a göre, "paydaş yaklaşımı, tüm paydaşlar için olabildiğince çok katma değer oluşturulması" dır (Garriga, 2014: 490). Bu paradigmatik yaklaşım aşağıda inceleneceği üzere, COBIT-5 içerisinde "paydaş ihtiyaçları" modeli ile ilk ilkeye yedirilmiş durumdadır.

Paydaşların memnuniyeti de toplam kalite yaklaşımının temel ilkelerinden birisidir. Paydaşların memnuniyeti için istediğini bilmeye ve dolayısıyla paydaşların ihtiyaçlarının neler olduğunun tespit edilmesi gerekir. Bu yaklaşımın aslında ilk olarak Osmanlı'daki Ahilik teşkilatında mevcut olduğu iddia edilmektedir (Karatop vd., 2011: 1112). Dolayısıyla, paydaşların ihtiyaçlarını karşılama yaklaşımının toplumsal ve tarihsel gerçeklik olarak Türk toplumunun yapısında olduğu ve bu nedenle COBIT-5 çerçevesi kolaylıkla benimsenebilir.

COBIT-5 yaklaşımının ve yönetişim paradigmasının özünü oluşturan paydaşların ihtiyaçlarına göre, bir organizasyonel yapılanma ve kurumsal iş amaçları doğrultusunda hizalanacak BT hedefleri ve gerçekleştirici amaçlarının kurgulanması gerektiğini savunur. (ISACA, 2012) Buna göre paydaş ihtiyaçları temel belirleyici olmalıdır. Ayrıca, bu ihtiyaçlar dönemsel olarak belirlenerek kurumsal hedefler, BT hedefleri ve gerçekleştirici hedefleriyle hizalı olup olmadıkları değerlendirilmelidir. Buna göre bakıldığında KA dinamiklerinde temel paydaşlar olan KK üyelerinin ihtiyaçlarının belirlenmesi büyük önem arz etmektedir. KK ihtiyacı sadece yılda iki defa toplantı yapmak değil, yapılandırılmış bir şekilde KA dinamiklerinden nasıl yararlanabilecekleri, sinerji oluşturma olasılı̆̆ 1 , bölgesel potansiyeller açısından oluşturulabilecek işbirliği ve ortaklıklar ile diğer destek programları dâhil olmak üzere pek çok yelpazede ihtiyaçlarının yansıtılabilmesi gerekir. Sadece KK değil, YK, GS ve iç birimlerin ihtiyaçları da dikkate alınabilmelidir.

\section{HEDEF BASAMAKLARI UYGULAMA MODELI}

KA için COBIT-5 ilkelerinin uygulama biçiminin modellenmesinden sonra ilk ilke olan paydaş ihtiyaçlarını karşılamak için gerekli olan ve "goals cascade" olarak ifade edilen hedef basamakları sistematiğinin de KA özelinde modelleştirilmesi gerekmektedir. $\mathrm{Bu}$ bölümde hedef basamakları sistematiği kullanılarak KA iç ve dış paydaşlarının ihtiyaçlarının nasıl KA kurumsal hedefleri haline gelmesi gerektiği ve COBIT-5 yönetişim hedefleri olan katma değer üretmek, risk ve kaynak optimizasyonları KA ortamında nasıl gerçekleştirilebilir konusunda analizler ve modellemeler yapılacaktır. 
KA paydaşları için katma değer oluşturmak amacıyla var olurlar. Bu nedenle, kalkınma ajansının büyük ölçekli/küçük ölçekli olsun veya olmasın bir yönetişim hedefi olarak katma değer oluşturması beklenir. Kurumsal hedeflere ulaşabilme, katma değer oluşturma, risk optimizasyonu, kaynak optimizasyonunun fayda gerçekleştirme ile aynı eksen ve doğrultuda hizalanması durumunda paydaşların ihtiyaçlarını karşıladığı ölçüde gerçekleştirilebilecektir. Faydalar içsel ve dışsal pozitif faydalar olarak belirlenebilir.

İçsel-dışsal kaynaklı olabilen risklere karşı alınacak önlemler, risklerin etki dereceleri, olasılıkları ve sıklık dereceleri ile yakından ilişkili olup, kalkınma ajansının riski kabul etmesi, azaltması, sakınması veya transfer etmesi risk iştahı ve hazmetme kapasitesi kadar eldeki kaynaklar ve elde edilecek fayda ile yakından ilişkili olabileceğinden dolayı risk yönetimi de fayda ile kaynaklar arasında hizalanmak durumunda kalır. Ancak bu durumda paydaşların ihtiyaçları doğrultusunda katma değer artışı da elde edilebilecektir. Dolayısıyla, yönetişim sistemi değer üretme, fayda, risk ve kaynak değerlendirme kararları alınırken tüm paydaşların ihtiyaçlarını ve önceliklerini dikkate almalıdır. Her karar için kimler fayda sağlıyor? Hangi riski kimler nasıl yönetiyor? Hangi kaynaklar ne oranda kullanılmalıdır? Temel soruları cevaplanabilmelidir.

Paydaşların eyleme geçirilebilecek KA stratejisi altında tekrardan yapılanması büyük önem arz etmektedir. Bu nedenle COBIT-5 hedef basamakları, paydaşların ihtiyaçlarını özgün, eyleme geçirilebilir ve özelleştirilmiş kalkınma ajansının hedefleri, BT-bağlantılı hedefler ve gerçekleştirici hedefler halinde açıklayan bir mekanizma olarak kurgulanmıştır (ISACA, 2012).

Şekil 4'ten anlaşılacağı üzere, COBIT-5 çerçevesinde kullanılan en temel yaklaşım hedef basamakları sistematiğidir. Bu sistematik olarak her kuruma uygulanabilecek özellikte geliştirilmiştir. Buna göre, her kurumun içerisinde bulunduğu çevresel etmenler bir ekosistem meydana getirmekte olup, bu sosyal, ekonomik, ekolojik, bürokratik ve kültürel ekosistemin kurumun paydaşlarının ihtiyaçlarını etkilediği varsayılmaktadır. Dolayısıyla bu ekosistem dikkate alınarak ulusal, bölgesel ve yerel paydaşların ihtiyaçları kurumsal fayda, risk ve kaynak optimizasyonu ile birlikte dikkate alınmalıdır. Kurumsal hedefler bu belirlenmiş olan paydaş ihtiyaçları çerçevesinde biçimlendirilmektedir. Her kurumsal hedefin gerçekleştirilebilmesi için mutlaka bir bilişim sistemi, aracı veya donanımı gibi varlıklara ihtiyaç duyduğundan dolayı bu kurumsal hedefler için bilgi teknolojisi bağıntılı yenilik hedefleri belirlenir. Kurumsal hedefler ile bilgi teknolojileri hedefleri mali destekler, vatandaş memnuniyeti, içsel ve büyüme öğrenme diğer beş ana eksene göre tasnif edilmektedir. En nihayetinde gerçekleştirici hedefleri de bunlara göre belirlenmektedir. Dolayısıyla COBIT-5 hedef basamakları yaklaşımı kurumu çevresiyle bütünleşik ve etkileşim içerisinde sibernitik ve değişken bir sistem olarak ele almakta ve hedefler ile süreçleri de buna göre yapılandırmak gerektiğini savunmaktadır. 
Şekil 4. COBIT-5 Hedef Basamakları

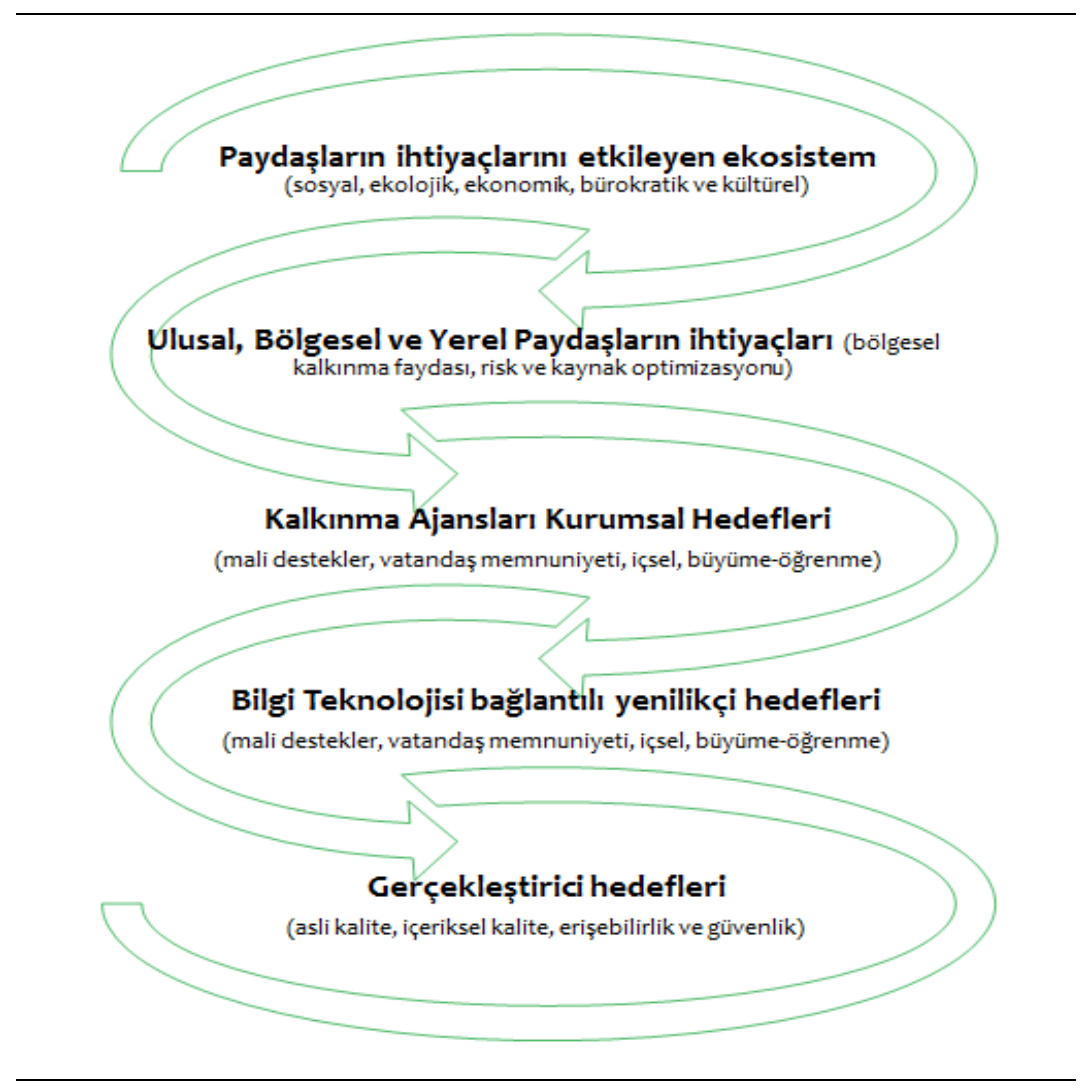

Kaynak: ISACA (2012)

\section{GÖRECELILIIK VE DİJITTAL GÖRELILIIK}

Son yıllarda akademik literatürde kamu politikası ve kamu yönetimi alanlarında diğer disiplinleri de etkileyecek ölçüde güçlü bir "yorumcu dönüş" görülmektedir (Hay, 2011). Kamu yönetimi ve politik araştırma alanında yorumcu analizlerin artan bir hızla kullanılması yanında kamusal alandaki çatışma ve tartışma alanlarındaki kullanışlılık potansiyeli üzerinde kapsamlı analizler yapılabilmiştir (Lejano ve Leong, 2012). Birçok düşünür tarafsız bir bilim, yani ideolojiden bağımsız, doğrunun bire bir temsilini veren toplum bilimleri anlayışına kuşku ile bakmışlardır. Örneğin, postmodernizmin temelini oluşturan görelilik "hermeneutics" yaklaşımı, pozitivist toplum bilimler anlayışını yadsımaktadır. Daha sonraları postmodernistler tarafindan da benimsenen yorumcu görelilik anlayışına göre, toplum bilimlerde değişken olan yorumlar belirleyici olacaktır.

Görelilik kuramının dijital alanlara uygulanmasıyla özellikle stratejik bilgi, veri, enformasyon, görüntüler, sesler ve arşivlerin hepsinin 0 ve 1 mantı̆̆ıyla ardışık bir şekilde ayrıştırılabilen elektrik voltlarından ibaret olduklarını da dikkate almak gerektiği 
anlaşılmaktadır. Artık görünür olan kâğıtlar, klasörler, kitaplar, belgeler, film bantları vb. gibi pek çok klasik bilgi ve veri taşıyıcısının artık sadece silikon ortamlardaki elektrik voltlarına dönüştürüldüğü görülmektedir. Dolayısıyla bilginin ne olduğu konusu ta tartı̧̧malı hale gelmiş̧ir.

Doğal olarak yorum, değer yargıları, zaman ve yer boyutlarına göre kişiden kişiye farklılıklar göstereceğinden dolayı yorumların değişkenliği ve yaklaşımların farklılığı üzerinde durmak önem arz etmektedir. Bu noktadan olaya bakıldığında, bilimsel disiplinlerin inceleme nesnesinin veya alanlarının çok belirgin bir şekilde ifade edilmesi imkânsız olabilmektedir. Çünkü insan ihtiyaçları, şartları ve yorumları farklı olacağından belirli bir sınır tayin etmek güç olacaktır. Ancak mevcut durum itibariyle kendi algımız ve kabullerimiz doğrultusunda izafi sınırlar çizilebilse de bunlar her zaman ve her yerde geçerliliğini koruyamayabilir. Bu bağlamda örgütler veya kamu kurumları için yapılan çözüm önerilerinin tek tipçi olmaması gerektiği söylenebilir. Bu nedenle de COBIT-5 ile önerilen değişken paydaş ihtiyaçlarına göre kurumsal yapılanma savı anlamlı ve desteklenebilir bir nitelik arz etmektedir.

\section{SONUÇ}

Yukarıda kısaca ilişkilendirilen görelilik teorisi ve bu teoriden beslenen çerçeve standartların da tek tipçi ve tek doğruculuktan vazgeçerek gelinen noktada genellemelerden uzaklaşılarak ve pozitivist anlayışların terk edilerek zaman, mekân ve öznel durumların özelinde hususileştirilebilecek esnek yaklaşımların benimsenmesinin bir paradigma geriliminin muhtemel nedenleri olarak değerlendirilmektedir. Bunun da COBIT-5 paydaş ihtiyaçlarını karşılayacak şekilde yapılanma ilkesi ile örtüştüğü görülmektedir. Dolayısıyla COBIT-5 çerçevesindeki yapılanmanın DDK raporu ile tespit edilmiş olunan sorunlardan birisi olan tek tipçi yapılanma sorununu çözebilecek yetkinliği sağlayabildiği ve bunun kavramsal ve kuramsal olarak ilgili teorilerle ilişkilendirilebildiği, düşünsel ve felsefi boyutunun derinliğinin ispatlanabildiği ortaya konulabilmektedir.

Atomdan galaksilere kadar alt ve üst sistemlerin düzenli varlığı ve bunların birbirileriyle olan ilişkilerindeki mükemmellik, suni sistemlerin doğru bir şekilde yapılandırılmaları gerekliliğini ortaya koymuştur. Burada dikkat edilmesi gereken yukarıdaki analizlerle paralel olarak tek tipçi yaklaşımların doğal ortamda fitrat kanunlarıyla da uyumlu olmamasıdır. Yapılması gereken, genel çerçevede tek tipçilik olabilirken detaylarda ilgili bölgenin öncelikleri, kapasite ve ihtiyaçlar doğrultusunda gerekli esnekliğe sahip olmalarının sağlanmasıdır.

Kalkınma ajanslarının tek tipçiliği ile ilgili sorun görelilik ve dijital görelilik değerlendirilebilir mi?

Tek tipçilik sorununun iki farklı standart kapsamındaki kısaca değerlendirmelerin sonucuna göre, tek tipçilik COSO kontrol amaçları ve bileşenleri açısından bir sorun olarak dikkate alınmayabilmekteyken COBIT-5 çerçevesine göre bir yönetişim sorunu olarak dikkate çekmektedir. Bu sorunun giderilmesi için Kalkınma Bakanlığı tarafından hazırlanan eylem planlarında hem Bakanlık ve hem de KA tarafından alınacak önlemler belirtilmiştir. Ancak sadece yönetim kurulu ile kalkınma kurulu ile ilgili değiş̧ikliklerle 
bölgedeki sorumlulukların gözden geçirileceği ifade edilmekte olduğu gibi henüz bu hususlarda yasal bir düzenleme ve idari değişikliklerin yapılmamış olduğu dikkate alındığında bu konuda ek önlemlerin alınması gerektiği söylenebilir. Çünkü görelilik yaklaşımda toptancılık ve tek tipçilik kabul edilemez klişe gibi reddedilir. Bu nedenle de görelilik ve tek tipçilik sorun olarak kabul edilmektedir. Bu kapsamda yapılabilecek ek önlemlerden birisi olarak, bölgesel kaynak ve ihtiyaçlara göre ilgili paydaşların istediği şekilde bir kurumsal yapı ve hedeflerin ortaya konulabilmesine olanak sağlayacak bir teşkilatlanma imkânının sağlanması belirtilebilir.

COBIT-5 çerçevesi tek tipçilik sorununa nasıl bir çözüm getirmektedir ve bu olanaklı midır?

COBIT-5 yaklaşımının ve yönetişim paradigmasının özünü oluşturan paydaşların ihtiyaçlarına göre, bir organizasyonel yapılanma ve kurumsal iş amaçları doğrultusunda hizalanacak BT hedefleri ve gerçekleştirici amaçlarının kurgulanması gerektiğini savunur (ISACA, 2012). Buna göre paydaş ihtiyaçları, temel belirleyici olmalıdır. Ayrıca kurumsal ihtiyaçlar dönemsel olarak belirlenerek kurumsal hedefler, BT hedefleri ve gerçekleştirici hedefleriyle hizalı olup olmadıkları değerlendirilmelidir. Buna göre KA dinamiklerinde temel paydaşlar olan KK üyelerinin ihtiyaçlarının belirlenmesi büyük önem arz etmektedir. KK ihtiyacı sadece yılda iki defa toplantı yapmak değil, yapılandırılmış bir şekilde KA dinamiklerinden nasıl yararlanabilecekleri, sinerji oluşturma olasılı̆ğ, bölgesel potansiyeller açısından oluşturulabilecek iş birliği ve ortaklıklar ile diğer destek programları dâhil olmak üzere pek çok yelpazede ihtiyaçlarının yansıtılabilmesi gerekir. Sadece KK değil, YK, GS ve iç birimlerin ihtiyaçları da dikkate alınabilmelidir.

COBIT-5 ile getirilebilecek olan çözümleme görelilik ve dijital görelilik çerçevesinde teorik ve kavramsal olarak nasıl konumlandırılabilir?

Sosyal bilimlerde yorumcu yaklaşımlar çokça kullanılsa da bu yaklaşımın özellikle ampirik çalışmalarda nasıl olması gerektiğine dair bilgi kıtlığı nedeniyle uygulamada farklılıklar gösterebilmektedir. Aslında bu yorumcu yaklaşımın genelde nasıl olmasına dair de çok az rehber kaynak mevcut olmasına rağmen BT alanlarındaki araştırmalarda yorumculuğun nasıl kullanılacağına dair araştırmalara da ihtiyaç vardır (Butler, 1998).

BT'nin her alanda olduğu gibi bilgi kaynaklarına erişim, yorumlama ve iletişimde yaygınlaşması ve yoğunlaşmasıyla insan varoluşuyla dijital teknolojinin temellerini anlama açısından üretken bir mantık (productive logic) geliştirmek noktasında dijital baskıya maruz kalan yorumcu anlayışın günümüzde artık "dijital metafizik"e karşıt olarak "dijital ontoloji" üzerinde temellendirilen "dijital hermeneutics" gibi paradigmaların kullanıldığ görülmektedir. Bu çerçevede geliştirilmiş olan "üretken mantık", çağdaş hermenütik yaklaşımı yadsıyacak şekilde mevcut bilimin kurgulamış olduğu öz-anlamayı aşarak ve temel kavramlarını gözden geçirerek yeni bir araştırma dönemine girildiğinin işaretlerini vermektedir (Capurro, 2010). Üretken mantığın dijital yorumlama ile sürdürülebilir bir şekilde katma değer üreterek BT hedeflerine, kurumsal hedeflere ve dolayısıyla paydaşların ihtiyaçlarının karşılanması da olanaklı olabilecektir.

COBIT-5 ile gelinen noktada her kurumun paydaşlarının ihtiyaçlarının farklı olabileceği dikkate alınarak paydaşlar tarafından yapılan yorum ve ihtiyaç taleplerine uygun 
kurumsal hedeflerin ortaya konulması önermesi pozitivist bilim anlayışının çıkmazlarının giderilmesi noktasında bir cevap olabilmektedir.

DDK tarafından yapılmış olan tek tipçi yapılanmanın yorumsalcılık akımı çerçevesinde bir sorun olarak ifade edilebileceği söylenebilir. Çünkü tek tipleme yaklaşımı genelleyici bir yaklaşım olup farklılıkların olabileceğini dikkate almayan ve yerel dinamiklerle bölgesel potansiyellere göre gerekli olabilecek yapılanmalardaki farklılıkları dışlayıcı bir nitelik göstermektedir.

\section{KAYNAKÇA}

Aykın, H., Arslanbaş, M., Dere, A., Özçelik, A., Boyali, C., Ceceli, F. vd. (2014). Kalkınma Ajansları İnceleme ve Araştırma Raporu (Hizmete Özel). Ankara: Cumhurbaşkanlığı Devlet Denetleme Kurulu. [Erişim: 14.06.2016] http://www.tccb.gov.tr/assets/dosya/20140130-2014-03.PDF

Butler, T. (1998). Towards a hermeneutic method for interpretive research in information systems. Journal of Information Technology, 13(4), 285-300. doi:10.1057/jit.1998.7

Capurro, R. (2010). Digital hermeneutics: an outline. AI \& society, 25(1), 35-42.

Efe, A. (2015). Türkiye'de Kalkınma Ajansları için bir Yönetişim Modellemesi: COBIT5. Basılmamış Doktora Tezi. Ankara: TODAİE

Garriga, E. (2014). Beyond stakeholder utility function: Stakeholder capability in the value creation process. Journal of Business Ethics, 120(4), 489-507. doi:10.1007/s10551-013-2001-y

Hay, C. (2011). Interpreting interpretivism interpreting interpretations: The new hermeneutics of public administration. Public Administration, 89(1), 167-182. doi:10.1111/j.1467-9299.2011.01907.x

ISACA (2012). COBIT 5: A Business Framework for the Governance and Management of Enterprise IT. Rolling Meadows, IL: ISACA.

Karatop, B., Karahan, A. G., \& Kubat, C. (2011). First Application of Total Quality Management In Ottoman Empire: Ahi Organization. In 7th Research/Expert Conference with International Participations" QUALITY (pp. 1109-1114). June 0104, Neum, B\&H. [Erişim: http://www.quality.unze.ba/zbornici/QUALITY\%202011/184-Q11-188.pdf

KB-BGYUGM (2014). Devlet Denetleme Kurulu Kalkınma Ajansları Araştırma ve Inceleme Raporu Kapsamında Alınacak Tedbirler. Hizmete Özel. Ankara: Kalkınma Bakanlığı.

Lejano, R. P., \& Leong, C. (2012). A hermeneutic approach to explaining and understanding public controversies. Journal of public administration research and theory, 22(4), 793-814. doi: 10.1093/jopart/mus001

TBMM (2006). 5449 Sayll Kalkınma Ajanslarının Kuruluşu, Koordinasyonu ve Görevleri Hakkında Kanun Genel Gerekçesi. [Erişim: 05.09.2014], 
http://www.dika.org.tr/photos/files/Kalk\%C4\%B1nma\%20Ajanslar\%C4\%B1n\%C4 $\% \mathrm{~B} 1 \mathrm{n} \% 20 \mathrm{Kurulu} \% \mathrm{C} 5 \% 9 \mathrm{Fu}, \% 20 \mathrm{Kooordinasyonu} \% 20 \mathrm{ve} \% 20 \mathrm{G} \% \mathrm{C} 3 \% \mathrm{~B} 6$ revleri\%2 0Hakk\%C4\%B1nda\%20Kanunun\%20Genel\%20Gerek\%C3\%A7esi.pdf 